\title{
Role of G Protein-Coupled Receptor Kinase-2 \\ in Peroxisome Proliferator-Activated Receptor Gamma-Mediated Modulation of Blood Pressure and Renal Vascular Reactivity in SHR
}

\author{
Zivar Yousefipour Adebayo Oyekan Mohammad Newaz \\ Center for Cardiovascular Diseases, Texas Southern University, Houston, Tex., USA
}

\section{Key Words}

Peroxisome proliferator-activated receptor $\gamma$.

Hypertension $\cdot G$ protein-coupled receptor kinase-2 .

$\mathrm{G}$ protein-coupled receptor $\cdot$ Vascular reactivity $\cdot$ Renal perfusion

\begin{abstract}
Background: Peroxisome proliferator-activated receptor $\gamma$ (PPAR $\gamma$ ), a nuclear transcription factor, modulates the expression/activity of $G$ protein-coupled receptors (GPCRs), but its role in GPCR signaling is not clear. Increased GPCR kinase-2 (GRK-2) activity and receptor desensitization have been reported in hypertension. Method: In this study we investigated the role of GRK- 2 in PPAR $\gamma$-mediated blood pressure regulation in hypertension. SHR or WKY rats were treated with GW1929, a selective PPAR ligand $(0.5 \mathrm{mg} / \mathrm{kg} / \mathrm{day})$, or vehicle for 2 months. Systolic blood pressure (tail cuff plethysmography), whole kidney perfusion (laser scanner) and renal vascular reactivity (isolated perfused kidney) was determined. Results: GW1929 significantly reduced blood pressure $(20 \pm 1 \%)$ and increased renal perfusion (61 $\pm 3 \%)$ in SHR compared to WKY rats. Vasoconstriction to phenylephrine $(100 \mu \mathrm{g})$ in the isolated perfused kidney was greater in SHRs $(29 \pm 1 \%)$ compared to WKY rats and this was abolished by GW1929. GW1929 enhanced acetylcholine-induced (30-300 $\mu \mathrm{g})$ and sodium nitroprusside-induced vasodilatation in SHR by $46 \pm 2 \%(p<0.05)$ and $33 \pm 2 \%(p<0.05)$,
\end{abstract}

respectively. Isoprenalin-induced (5-30 $\mu \mathrm{g})$ vasodilatation was $43 \pm 2 \%$ lower in SHR compared to WKY and GW1929 enhanced this vasodilatation by $55 \pm 2 \%$. In SHR kidney, GW1929 enhanced expression of PPAR $\gamma$ mRNA (34 $\pm 1 \%$ ) but reduced that of GRK-2 (31 $\pm 3 \%$ ). Conclusion: We suggest that downregulation of PPAR $\gamma$ but upregulation of GRK2 increases blood pressure and impaired renal vascular reactivity in SHR and that PPAR $\gamma$-mediated improvement in hypertension may involve transcriptional regulation of GRK2 function.

Copyright $\odot 2009$ S. Karger AG, Basel

\section{Introduction}

G protein-coupled receptors (GPCRs) are regulated by multiple mechanisms that serve to adapt their signaling ability to a constantly changing environment. One of the most rapid mechanisms modulating agonist-activated receptors is phosphorylation by $\mathrm{G}$ protein-coupled receptor kinases (GRKs) resulting in uncoupling of the GPCR-mediated transduction process [1]. This phenomenon termed desensitization involves several processes including phosphorylation, sequestration/internalization and degradation of receptor protein [1]. Seven distinct GRKs (GRK17) have been identified to date [2]. GRKs 1 and 7 belong to the rhodopsin family, GRKs 2 and 3 belong to $\beta$-adrenergic receptor kinase ( $\beta A R K)$ family and GRKs 4,5

\section{KARGER}

(C) 2009 S. Karger AG, Basel

Fax +4161306 1234 E-Mail karger@karger.ch www.karger.com www.karger.com/ajn
Mohammad Newaz, MD, PhD

Center for Cardiovascular Diseases

College of Pharmacy and Health Sciences, Texas Southern University Houston, TX 77004 (USA)

Tel. +1 713313 1890, Fax +1 713313 4342, E-Mail newaz_ma@tsu.edu 
and 6 belong to the GRK4 family [1-4]. The phosphorylation of GPCRs, including $\beta$-adrenergic receptors, leads to the binding of a member or members of the arrestin family and uncoupling of the receptors from the $G$ protein complex decreasing its functional response.

Because of the lack of drug acting directly on GRKs, the physiological function of GRK-2 ( $\beta A R K)$ is still largely unknown. The role of GRK-2 in the pathology of hypertension has long been postulated and special emphasis was given to its function in cardiac development and its role in regulating cardiac $\beta$-adrenergic response. The fundamental role of GRK-2 in cardiac development was confirmed in 1996 [5]. Accordingly, transgenic mice overexpressing either $\beta A R K 1$ or a peptide inhibitor of $\beta A R K 1$ in the heart demonstrated that the activity of the kinase significantly contributes to the regulation of myocardial contractility [6]. Similarly, Eckhart et al. [7] showed that vascular overexpression of GRK-2 attenuated $\beta$-agonist-stimulated vasodilatation. This observation was corroborated by recent works suggesting that embryonic developmental abnormalities following cardiac-specific ablation of GRK-2 may be attributable to the extracardiac effect of GRK-2 [8]. Increased expression and activity of GRK-2 have been reported in both hypertensive subjects $[9,10]$ and in animal models of hypertension [11]. Penela et al. $[12,13]$ showed in an aortic smooth muscle cell line that physiological vasoconstrictors markedly enhanced GRK-2 promoter activity resulting in increased GRK-2 mRNA expression suggesting that the expression of GRK-2 is strongly controlled at the transcriptional level.

Peroxisome proliferator-activated receptors (PPARs) are ligand-activated transcription factors that belong to the nuclear receptor superfamily and consist of three isoforms named PPAR $\alpha$, PPAR $\delta$ (or $\beta$ ), and PPAR $\gamma$. PPAR $\gamma$ is expressed in adipose tissue, endothelial cells, and vascular smooth muscle cells [14]. The role of PPAR $\gamma$ in vascular function has been studied extensively in diabetics [15] as well as in nondiabetics [16] and convincing evidence emerged that PPAR $\gamma$ activation contributes to vascular function [17].

Involvement of PPAR $\gamma$ in modulating renal vascular function is less well characterized. Previously, we have shown that PPAR $y$ ligand mediated improvement in renal vascular reactivity in a disease model like glycerolinduced acute renal failure $[18,19]$. Similarly, Efrati et al. [20] reported PPAR $\gamma$ ligand-mediated improved renal vascular function and suggest that PPAR $\gamma$ effect in the kidney extends beyond glycemic and lipidemic control. This effect is probably via transcriptional regulation of vasoactive components such as catecholamine ( $\beta$-adrenergic receptor), angiotensin II ( $\mathrm{AT}_{1}$ receptor), and endothelin-1 ( $\mathrm{ET}_{\mathrm{A}}$ receptor) that works as GPCRs [21]. PPAR $\gamma$ ligands may also potentiate $\beta$-adrenergic vasodilatation via activation of Raf/MEK/ERK1/2 signaling pathways [22] where activated ERK1/2 reduced GRK-2 activity [23, 24] and, therefore, plays an important role in GPCR signaling cascade. Although the connection between PPAR $\gamma$ and GRK-2 has never been examined the possibility of PPAR $\gamma$ influencing GRK-2 was never excluded either. At the same time, numerous studies demonstrated the possibility that PPAR $\gamma$ transcriptionally regulates the regulators of $G$ protein signaling (RGS) molecules $[25,26]$ opening up the possibility of PPAR $\gamma$-dependent regulation of GRK-2 (also an RGS family of protein). In this study, we have tested the hypothesis that PPAR $\gamma$ ligandmediated improvement in blood pressure and renal vascular reactivity may be attributed to a transcriptional effect of PPAR $y$ on GRK-2 expression. We, therefore, activated PPAR $\gamma$ in hypertensive rats to examine the association of improvement in blood pressure/renal vascular reactivity with that of GRK-2 expression.

\section{Materials and Methods}

Male (300-350 g, Harlan) WKY and SHR rats were divided into groups: control and treatment ( $\mathrm{n}=6-8$ rats/group). Treatment group received $0.5 \mathrm{mg} / \mathrm{kg}$ of GW1929, an orally active PPAR $y$ ligand, for 2 months while control rats received an equal amount of vehicle (saline). Rats were housed in controlled environment with a 12-hour light and dark cycle and free access to food and water. Systolic blood pressure (SBP) was measured before and 2 months after the treatment period using tail cuff plethysmography (Apollo 179; IITC, Woodland Hills, Calif., USA).

Whole Kidney Perfusion

At the end of the treatment, rats were anesthetized with pentobarbital (40 mg/kg, i.p.) and whole kidney perfusion was determined using a laser scanner (Moor Instrument, Axminster, UK). A mid-ventral incision approximately $5 \mathrm{~cm}$ long was then made and the abdomen was kept open using a clamp. Both right and left kidneys were identified and cleaned gently with a saline-soaked cotton bud to separate them from any surrounding tissues. A laser scanner was positioned directly over a set area covering both kidneys and programmed using the software program attached to the laser scanner camera. Three repetitive scans were performed and the mean value determined for each kidney. Renal perfusion was expressed as perfusion units per unit area of kidney.

\section{Rat Isolated Perfused Kidney Preparation}

Immediately after determination of whole kidney perfusion, isolated perfused kidney was used to measure renal vascular responses to vasoconstrictors and vasodilators. While still under anesthesia, the left renal artery was cannulated through the ab- 
dominal aorta and the kidney was perfused by means of a peristaltic pump (model 7515-10, Masterflex cartridge pump, Cole Parmer Instrument, Vernon Hills, Ill., USA) with warmed $\left(37^{\circ} \mathrm{C}\right)$, oxygenated $\left(95 \% \mathrm{O}_{2}\right.$ and $\left.5 \% \mathrm{CO}_{2}\right)$ Krebs-Henseleit buffer composed of $118 \mathrm{mM} \mathrm{NaCl}, 25 \mathrm{mM} \mathrm{NaHCO}_{3}, 1.9 \mathrm{CaCl}_{2}, 1.19 \mathrm{MgSO}_{4}$, $4.75 \mathrm{KCl}, 1.19 \mathrm{KH}_{2} \mathrm{PO}_{4}$, and $11.1 \mathrm{~mm}$ dextrose (pH 7.2). The flow of perfusate was adjusted in each kidney to obtain a perfusion pressure of $80-120 \mathrm{~mm} \mathrm{Hg}$. Mean flow rate was maintained within $8.5-13 \mathrm{ml} / \mathrm{min}$. The inferior vena cava was cut to allow the flow of perfusate and the kidney was removed from the surrounding fat and placed in an organ chamber prewarmed at $37^{\circ} \mathrm{C}$. The perfusion pressure was monitored constantly by means of a transducer (Transbridge, model TBM-4, World Precision Instrument, Sarasota, Fla., USA) which was connected to a computer by a signal manifold (model DI-720 and DI-205, DataQ Instruments). Because flow was maintained at a constant rate, change in perfusion pressure was used as an index of renal vascular resistance, an increase in perfusion pressure indicating vasoconstriction while a reduction indicates vasodilatation. To determine vasodilator responses baseline perfusion pressure was elevated with phenylephrine $(\mathrm{PE} ; 100 \mu \mathrm{M})$ in the buffer before adding the vasodilator agents. All responses were measured as the differences between the minimum pressure and the peak responses (for vasoconstriction) or the difference between the maximum pressure with $\mathrm{PE}$ $(100 \mu \mathrm{g})$ and the lowest response (for vasodilatation). Renal vascular response to PE (100 $\mu \mathrm{g})$, acetylcholine (Ach; 30-300 $\mu \mathrm{g})$, sodium nitroprusside (SNP; 5-30 $\mu \mathrm{g})$, and isoprenaline (5-30 $\mu \mathrm{g})$ was determined.

\section{GRK-2 and PPAR $\gamma$ Gene Expression by RT-PCR}

Whole kidney homogenates were prepared by homogenizing kidney tissues in RIPA buffer containing protease inhibitor (SC 24948; Santa Cruz Biotechnology, Santa Cruz, Calif., USA). The homogenate was processed to isolate total RNA using the RNeasy Mini kit from Qiagen (Valencia, Calif., USA) following the manufacturer's instructions. Total RNA was quantified and $100 \mathrm{ng}$ of the RNA was reverse transcribed to synthesize cDNA using ReactionReady first strand cDNA synthesis kit (Cat. No. C-03) from Super Array Bioscience (Frederick, Md., USA). The cDNA was then amplified using SYBR Green (Cat. No. PA-011) real-time PCR master mix from SA Bioscience in Bio-Rad iCycler real-time PCR equipment. Rat GRK-2 (Cat. No. PPR45759A) and PPAR- $\gamma$ (PPR47599A) specific primer sets were used (SA Bioscience) together with a primer set for GAPDH (PPR06557A) as the housekeeping gene for standardization. Each PCR amplification was performed in triplicate wells following PCR conditions prescribed for the SYBR Green PCR master mix by the manufacturer: $95^{\circ} \mathrm{C}$ for $15 \mathrm{~min}$ followed by 40 cycles of $95^{\circ} \mathrm{C}$ for $30 \mathrm{~s}, 55^{\circ} \mathrm{C}$ for $30 \mathrm{~s}$ and $72^{\circ} \mathrm{C}$ for $30 \mathrm{~s}$. A melting curve analysis was performed immediately after PCR cycles to assure that there were no primer dimers. Negative PCR controls including omission of reverse transcriptase or omission of cDNA or primers were used to validate each batch of template before use. Individual data were adjusted with GAPDH value and expressed as $\Delta \Delta \mathrm{ct}$.

\section{Statistical Analysis}

Response to agonists was expressed as peak change in perfusion pressure from their basal values. Data were presented as mean \pm SEM and comparisons were made within each group and between groups using ANOVA and Student's t test for significant

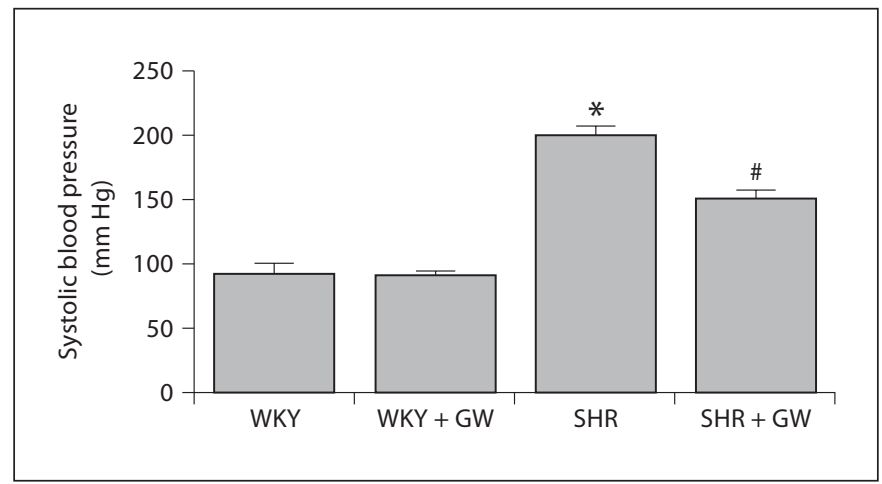

Fig. 1. SBP in WKY and SHR treated with GW1929 $(0.5 \mathrm{mg} / \mathrm{kg} ; 2$ months) or vehicle before and after treatment. Values are mean \pm SEM ( $\mathrm{n}=6-8$ rats/group). ${ }^{*} \mathrm{p}<0.05$ versus WKY; ${ }^{*} \mathrm{p}<0.05$ versus SHR.

differences. ANOVA was also used to determine differences in blood pressure and whole kidney perfusion values that were compared between groups while gene expression values were expressed as fold change. In all cases $\mathrm{p} \leq 0.05$ was considered significant.

\section{Results}

\section{Effects of PPAR $\gamma$ Induction on SBP and Whole}

Kidney Perfusion

Figure 1 illustrates that baseline SBP in SHR rats was $116 \pm 7 \%$ higher than that of the WKY rats (WKY: $81 \pm$ $11 \mathrm{~mm} \mathrm{Hg}$; SHR: $176 \pm 6 \mathrm{~mm} \mathrm{Hg})$. After a study period of 2 months, SBP in untreated SHR rose to $201 \pm 6 \mathrm{~mm}$ $\mathrm{Hg}$ but was reduced by $20 \pm 1 \%$ in GW1929-treated rats ( $\mathrm{p}<0.05$ ). Similarly, whole kidney perfusion (fig. 2) was significantly lower in SHR rats compared to that of WKY rats (WKY: $2.22 \pm 0.07$ perfusion units/unit area; SHR: $1.7 \pm 0.08$ perfusion units/unit area). PPAR $\gamma$ induction by GW1929 enhanced whole kidney perfusion in both WKY and SHR rats by $15 \pm 0.5 \%(\mathrm{p}<0.05)$ and $61 \pm 3 \%$ $(\mathrm{p}<0.01)$, respectively.

\section{Effect of GW1929 on Renal Vasoconstriction}

Basal perfusion pressure in the kidneys isolated from SHR rats was $29 \pm 2 \%(\mathrm{p}<0.05)$ higher than that in WKY rats (WKY: $100 \pm 4 \mathrm{~mm} \mathrm{Hg}$; SHR: $129 \pm 11 \mathrm{~mm}$ $\mathrm{Hg}$ ) (fig. 3), whereas in the GW1929-treated SHR group $(102 \pm 8 \mathrm{~mm} \mathrm{Hg})$ it was similar to that of WKY rats. The addition of PE $(100 \mu \mathrm{g})$ in the perfusate increased perfusion pressure in the kidneys from all groups. This vasoconstriction was $29 \pm 1 \%(\mathrm{p}<0.05)$ higher in kidneys 
Fig. 2. Representative scan (a-d) and quantification of whole kidney perfusion (e) measured by laser scanner in WKY (a), WKY + GW1929 (b), SHR (c) and SHR + GW1929 (d). Rats were treated with GW1929 $(0.5 \mathrm{mg} / \mathrm{kg})$ or their vehicle for 2 months. Values are mean \pm SEM $(n=6-8$ rats/group). ${ }^{*} \mathrm{p}<0.05$ versus WKY; ${ }^{\#} \mathrm{p}<0.05$ versus SHR.
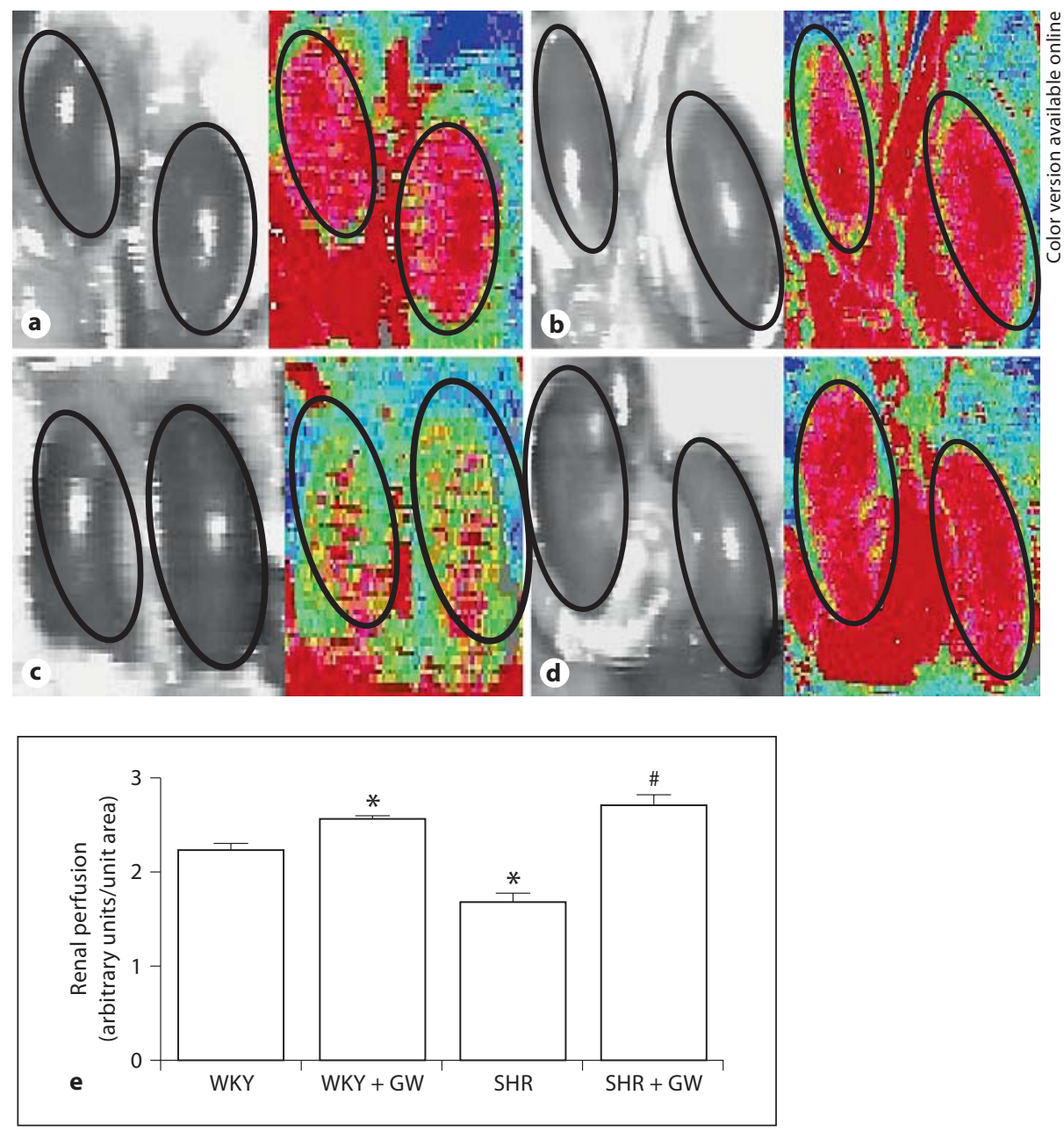

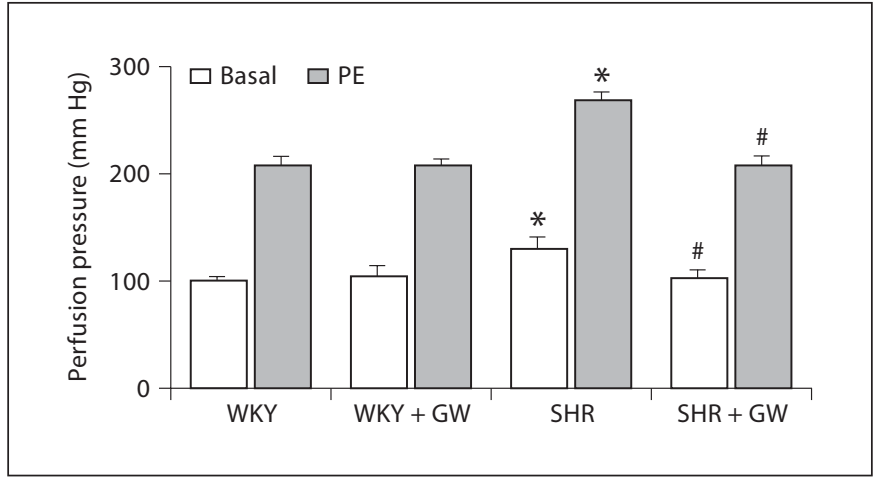

Fig. 3. Vascular response to PE $(100 \mu \mathrm{g})$ determined in kidneys from WKY and SHR rats treated with GW1929 $(0.5 \mathrm{mg} / \mathrm{kg} ; 2$ months) or vehicle. Values are mean \pm SEM ( $n=6-8$ rats/group). ${ }^{*} \mathrm{p}<0.05$ versus WKY; ${ }^{*} \mathrm{p}<0.05$ versus SHR without heparin. from the SHR than WKY rats (WKY: $208 \pm 7 \mathrm{~mm}$ Hg; SHR: $268 \pm 7 \mathrm{~mm} \mathrm{Hg}$ ). On the contrary, this enhancement in vasoconstrictor response was blunted in GW1929-treated SHR by $29 \pm 7 \%(\mathrm{p}<0.05)$ compared to that in vehicle-treated SHR.

\section{Effect of GW1929 on Endothelium-Dependent and \\ Endothelium-Independent Renal Vasodilatation}

We tested both endothelium-dependent (Ach) and endothelium-independent (SNP) vasodilatation in the isolated kidney from WKY and SHR rats with or without PPAR $\gamma$ induction. Ach-induced vasodilatation was reduced by $46 \pm 2 \%(\mathrm{p}<0.05)$ in SHR kidney compared to those from WKY rats (WKY: 24-55\%; SHR: 12-18\%) (fig. 4). GW1929 prevented this fall in Ach vasodilatation by maintaining vasodilatation to a level that is similar to that in WKY rats. Similarly, SNP vasodilatation was at- 


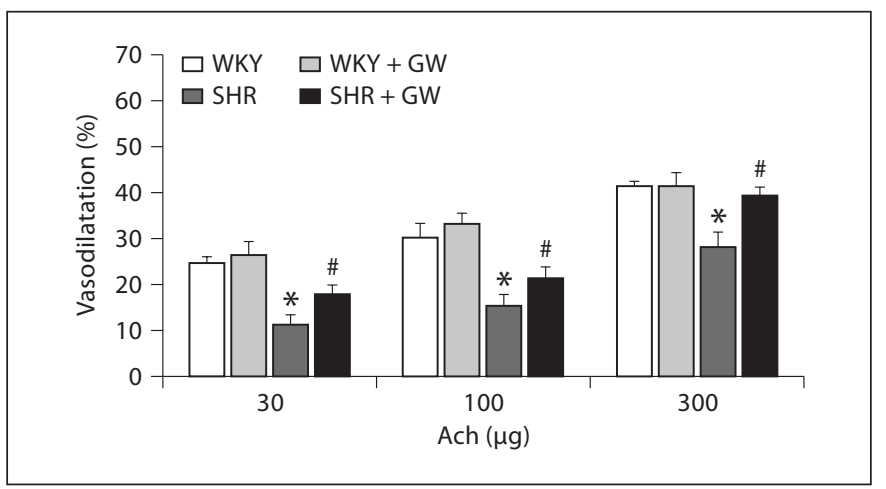

Fig. 4. Vascular response to Ach $(30-300 \mu \mathrm{g})$ determined in the PE $(150 \mu \mathrm{g} / \mathrm{l})$-preconstricted isolated perfused kidneys from WKY and SHR rats treated with GW1929 (0.5 mg/kg; 2 months) or vehicle. Values are mean \pm SEM $\left(\mathrm{n}=6-8\right.$ rats/group). ${ }^{*} \mathrm{p}<$ 0.05 versus WKY; ${ }^{*} \mathrm{p}<0.05$ versus SHR.

tenuated in kidney of SHR rats by $33 \pm 2 \%(\mathrm{p}<0.05)$ compared to that of WKY rats (WKY: 23-44\%; SHR: 18 26\%) and GW1929 prevented this fall in SNP dilatation to an extent similar to that of WKY rats (fig. 5).

\section{Effect of GW1929 on $\beta$-Adrenergic Stimulation-}

\section{Mediated Renal Vasodilatation}

We examined the vasodilator responses to isoprenaline as a representative of $\beta$-adrenergic stimulation where GRK-2 has been shown to have a profound regulatory effect. Isoprenaline-induced vasodilatation (fig. 6) was significantly lower $(43 \pm 2 \%$; $<<0.02)$ in kidneys from SHR rats than in WKY rats (WKY: $13-42 \%$; SHR: 6-27\%). PPAR $\gamma$ ligand GW1929 enhanced vasodilatation in SHR by $55 \pm 2 \%(\mathrm{p}<0.01)$ to a level similar to that of WKY rats.

\section{Effect of GW1929 on PPAR $\gamma$ and GRK-2 Gene}

\section{Expression in the Kidney}

RT-PCR results showed that PPAR $\gamma$ mRNA was $34 \pm$ $2 \%(\mathrm{p}<0.05)$ lower (fig. 7a) and GRK-2 mRNA was $69 \pm$ $6 \%(\mathrm{p}<0.05)$ higher (fig. $7 \mathrm{~b})$ in kidneys from SHR rats compared to kidneys from WKY rats. GW1929 significantly enhanced PPAR $\gamma$ mRNA expression $(34 \pm 1 \%)$ but attenuated GRK-2 mRNA expression (31 \pm 3\%) in SHR but not in WKY rats translating into a 2.4-fold increase in PPAR $\gamma$ gene expression in SHR after GW1929 treatment but a 17.8-fold reduction in GRK-2 expression in SHR.

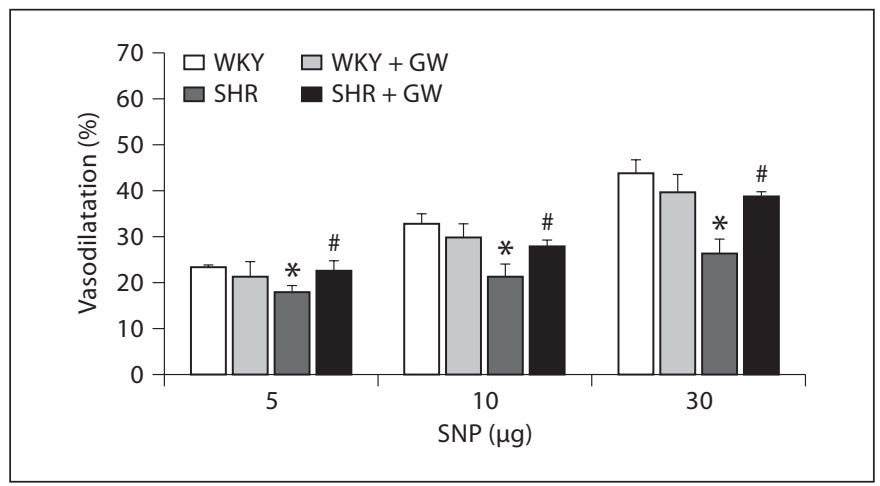

Fig. 5. Vascular response to SNP (3-30 $\mu \mathrm{g})$ determined in PE (150 $\mu \mathrm{g} / \mathrm{l})$-preconstricted isolated perfused kidney from WKY and SHR rats treated with GW1929 (0.5 mg/kg; 2 months) or vehicle. Values are mean \pm SEM $\left(\mathrm{n}=6-8\right.$ rats/group). ${ }^{*} \mathrm{p}<0.05$ versus WKY; ${ }^{*} \mathrm{p}<0.05$ versus SHR.

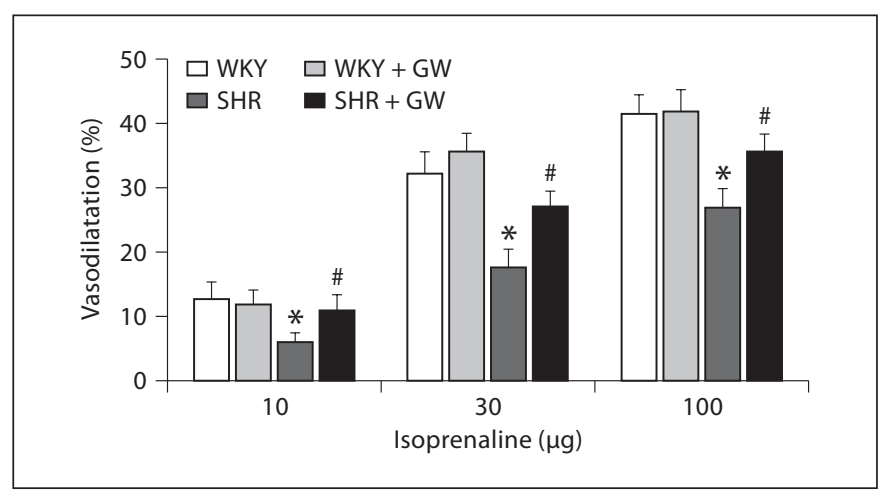

Fig. 6. Vascular response to isoprenaline (10-100 $\mu \mathrm{g})$ determined in PE $(150 \mu \mathrm{g} / \mathrm{l})$-preconstricted isolated perfused kidneys from WKY and SHR rats treated with GW1929 (0.5 mg/kg; 2 months) or vehicle. Values are mean $\pm \operatorname{SEM}\left(\mathrm{n}=6-8\right.$ rats/group). ${ }^{*} \mathrm{p}<$ 0.05 versus WKY; ${ }^{\#} \mathrm{p}<0.05$ versus SHR.

\section{Discussion}

We have shown in this study that GW1929, an orally active PPAR $\gamma$ ligand, prevented the increase in SBP in SHR. GW1929 treatment also enhanced whole kidney perfusion in hypertensive rats confirming the role of PPAR $\gamma$ in cardiovascular regulation. The most interesting observation from this study was the relationship observed between PPAR $\gamma$ and GRK-2, which suggests that PPAR $\gamma$-mediated improvement in vascular function may involve the GRK-2 gene. This observation was accompa- 

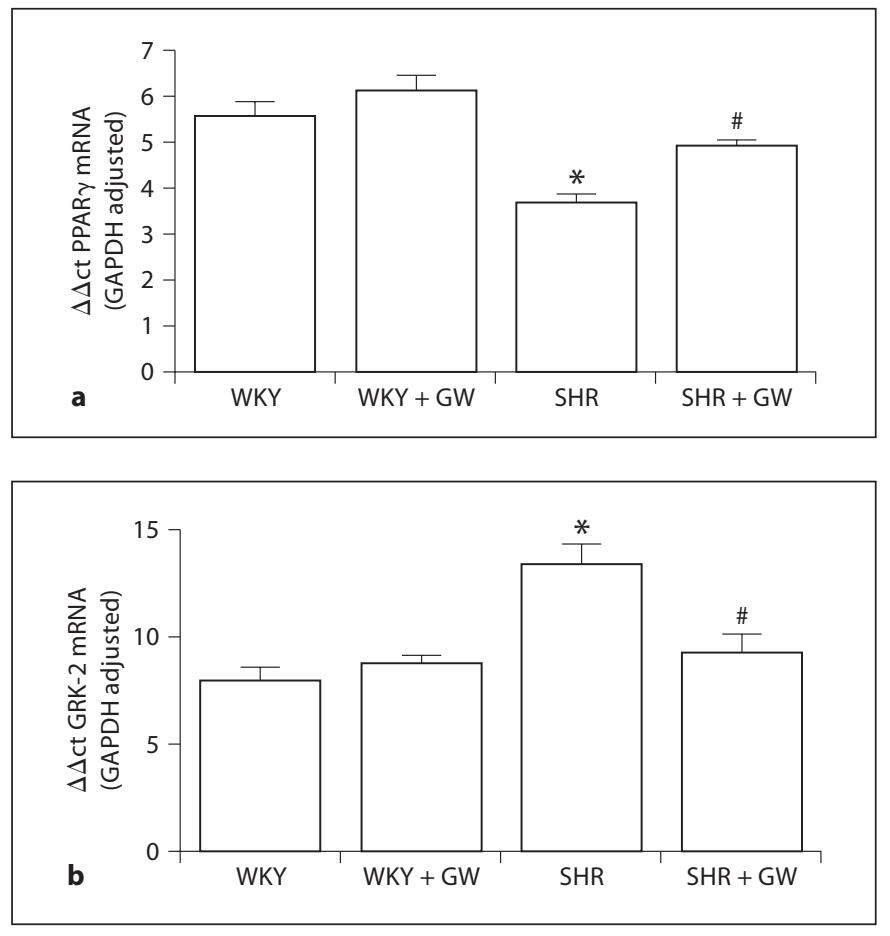

Fig. 7. Real-time PCR analysis of PPAR $\gamma(\mathbf{a})$ and GRK-2 (b) mRNA in total RNA isolated from WKY and SHR kidneys treated with GW1929 (0.5 mg/kg; 2 months) or vehicle. Values are mean \pm SEM ( $\mathrm{n}=6-8$ rats/group). ${ }^{*} \mathrm{p}<0.05$ versus WKY; $\mathrm{p}<0.05$ versus SHR.

nied by attenuation of vasoconstrictor response to PE but enhancement of both endothelium-dependent and endothelium-independent vasodilatation in hypertensive rats.

PPAR $\gamma$ is expressed in both endothelial cells and vascular smooth muscle cells making it possible that this receptor plays a role in regulating vascular tone and blood pressure [14, 27-30]. Indeed, PPAR $\gamma$ agonists including thiozolidinediones lower blood pressure in experimental hypertension, an effect that is at least partially independent of their insulin-sensitizing effect [31-34]. Similarly, in transgenic hypertensive mice, rosiglitazone improved relaxation of carotid arteries to Ach suggesting that the blood pressure-lowering effect of thiozolidinediones may be due to their direct impact on blood vessels [35]. To date, the underlying mechanisms are still under investigation. PPAR $\gamma$ activation may regulate blood pressure via modulation of endothelial vasoactive factors such as endothelin-1, prostacyclin, and nitric oxide. PPAR $\gamma$ may also directly reduce vascular smooth muscle cell tone through downregulation of angiotensin II receptor 1 [36]. It is also hypothesized that at baseline PPAR $\gamma$ suppresses gene expression in vascular cells to contribute to the maintenance of normal blood pressure [37]. Therefore, a reduced PPAR $\gamma$ may lead to a hypertensive phenotype similar to what we observed in this study. Interestingly, a majority of the vasoactive components that seem to be influenced by PPAR $\gamma$ mediate their effects through GPCR and, therefore, GRK-dependent regulation may also contribute to vascular tone. Conversely, PPAR $\gamma$-mediated vascular regulation may also be involved in regulating GRK activity.

The mechanism by which PPAR $\gamma$ ligands provide renoprotection is not totally clear at present. Identification of functional PPAR $\gamma$ receptors in renal glomerular and tubular tissues besides vascular tissues has raised the possibility that both systemic and vascular responses are involved in PPAR $\gamma$-mediated renal protection $[38,39]$. A considerable number of animal and human studies have shown that all PPAR $\gamma$ ligands are capable of producing small but significant changes in blood pressure level and their actions such as improvement in endothelial function, attenuation of sympathetic overactivity, or reduction of intracellular calcium content in vascular smooth muscle cells could be responsible for this effect [40]. Since renal perfusion is a direct reflection of afferent arteriolar pressure or SBP, a reduced SBP would automatically translate into an enhanced renal perfusion and this was a crucial observation in this study. Our data is in agreement with earlier animal $[41,42]$ and human studies [4345] that showed a significant blood pressure reduction and renoprotection by PPAR $\gamma$ ligands.

In this study, we proposed another modality for PPAR $\gamma$-mediated improvement in renal vascular function: PPAR $\gamma$ activation inhibits GRK-2. The role of GRK2 in hypertension has been studied extensively because of the observation of increased GRK-2 protein and mRNA expression in hypertension and its role in attenuating $\beta$-adrenergic vasodilator response. Experimental studies also show that vascular overexpression of GRK-2 in transgenic mice attenuates $\beta$-adrenergic receptor signaling and increased resting blood pressure [7]. At the same time, Ramos-Ruiz et al. [13] showed that physiological vasoconstrictors increased GRK-2 promoter activity of the GRK-2 gene transfected in human aortic smooth muscle cell line suggesting a role for GRK-2 in vascular function. It has been shown earlier that PPAR $\gamma$ can modulate the expression and activity of major endogenous vasoconstrictors such as angiotensin II, endothelin-1, thromboxane as well as their GPCRs. Therefore, it is possible that PPAR $\gamma$ may also have a transcriptional influence on GRKs that are the principal regulators 
of GPCRs. There is no evidence so far that PPAR $\gamma$ may have a direct influence on GRK-2 gene expression, although indirectly it may. PPAR $\gamma$ ligands have been shown to activate Raf-1/MEK/ERK $1 / 2$ pathway while activated ERK1/2 has been linked to enhanced GPCRmediated response. Interestingly, several reports confirmed that ERK1/2 phosphorylates GRK-2 leading to a reduced GRK-2 activity and downregulation of GRK-2 protein expression $[23,24]$. In this study, we have shown that PPAR $\gamma$-mediated improvement in blood pressure and vascular reactivity may be a direct influence of GRK-2 inhibition. This notion is based on our observation that reduced PPAR $\gamma$ expression in hypertension is associated with increased GRK-2 gene expression, which suggests that PPAR $\gamma$ may have a negative regulation on GRK-2 gene. Therefore, PPAR $\gamma$ activation will reduce GRK-2 and this may be the mechanism for PPAR $\gamma$ ligand-mediated reduction in blood pressure and improvement in vascular reactivity in the hypertensive rats. This hypothesis is further strengthened by our observation that PPAR $\gamma$ activation is associated with a reduced GRK-2 gene expression. These observations led to the possibility that PPAR $y$ transcriptionally regulates
GRK-2 gene expression. This notion is underscored by the fact that all the GRKs belong to the RGS family of proteins. Therefore, the presence of a common RGS protein binding domain [46] in GRK-2 gene raised the possibility of regulation by PPAR $\gamma$ since PPAR $\gamma$ has been shown to regulate some other RGS (RGS-2) during adipocyte differentiation [26]. Our findings of reduced GRK-2 mRNA in GW1929-treated SHR comply with this notion and suggest that PPAR $\gamma$ has a transcriptional effect on GRK-2 gene.

In summary, these results suggest that downregulation of PPAR $\gamma$ coupled with upregulation of GRK-2 may be responsible for hypertension and PPAR $\gamma$ ligand-mediated reduction in blood pressure and improved vascular function in SHR may involve transcriptional regulation of GRK-2.

\section{Acknowledgments}

This study was supported by National Institutes of Health grants HL03674 and HL59884 and American Heart Association grant BGIA 017369.

\section{References}

1 Ferguson SS: Evolving concepts in G-protein coupled receptor endocytosis: the role in receptor desensitization and signaling. Pharmacol Rev 2001;53:1-24.

$\checkmark 2$ Penn RB, Pronin AN, Benovic JL: Regulation of G-protein coupled receptor kinases. Trends Cardiovasc Med 2000;10:81-89.

-3 Sallese M, Mariggio S, Collodel G, et al: G protein coupled receptor kinase GRK4: molecular analysis of the four isoforms and ultrastructural localization in spermatozoa and germinal cells. J Biol Chem 1997;272: 10188-10195.

-4 Premont RT, Macrae AD, Stoffel RH, et al: Characterization of the $G$ protein coupled receptor kinase GRK4. Identification of four splice variants. J Biol Chem 1997;271:64036410 .

5 Jabber M, Koch WJ, Rockman H, Smith B, Bond RA, Sulik KK, Ross J, Lefkowitz RJ, Caron MG, Giros B: Essential role of $\beta$-adrenergic receptor kinases 1 in cardiac development and function. Proc Natl Acad Sci USA 1996;93:12974-12979.

-6 Koch WJ, Rockman HA, Samama P, Hamilton R, Bond R, Milano CA, Lefkowitz R: Cardiac function in mice overexpressing the beta-adrenergic receptor kinase or a beta ARK inhibitor. Science 1995;268:13501353.
7 Eckhart AD, Ozaki T, Tevaearai H, Rockman HA, Koch WJ: Vascular-targeted overexpression of $\mathrm{G}$ protein-coupled receptor kinase- 2 in transgenic mice attenuates $\beta$-adrenergic receptor signaling and increases resting blood pressure. Mol Pharmacol 2002; 61:749-758.

8 Matkovich SJ, Diwan A, Klanke JL, Hammer DJ, Marreez Y, Odley AM, Brunskill EW, Koch WJ, Schwartz RJ, Dorn GW: Cardiacspecific ablation of G-protein receptor kinase 2 redefines its role in heart development and beta-adrenergic signaling. Circ Res 2006;99:996-1003.

-9 Gros R, Benovic JL, Tan CM, Feldman RD G-protein coupled receptor kinase activity is increased in hypertension. J Clin Invest 1997;99:2087-2093.

10 Gros R, Tan CM, Chorazyezewski J, Kelvin DJ, Benovic JL, Feldman RD: G-protein coupled receptor kinase expression in hypertension. Clin Pharmacol Ther 1999;65:545551.

11 Gros R, Chorazyezewski J, Meek MD, Benovic JL, Ferguson SS, Feldman RD: G-protein coupled receptor kinase activity in hypertension: increased vascular and lymphocyte G-protein receptor kinase protein expression. Hypertension 2000;35:38-42.
12 Penela P, Murga C, Ribas C, Tutor AS, Peregrin S, Mayor F: Mechanisms of regulation of G protein coupled receptor kinases (GRKs) and cardiovascular diseases. Cardiovasc Res 2006;69:46-56.

13 Ramos-Ruiz R, Penela P, Penn RB, Mayor F Jr: Analysis of the human $G$ protein coupled receptor kinase 2 (GRK-2) gene promoter: regulation by signal transduction systems in aortic smooth muscle cells. Circulation 2000;101:2083-2089.

14 Marx N, Bourcier T, Sukhova GK, Libby P, Plutzky J: PPARgamma activation in human endothelial cells increases plasminogen activator inhibitor type-1 expression: PPARgamma as a potential mediator in vascular disease. Arterioscler Thromb Vasc Biol 1999;19:546-551.

15 Vinik A, Parson H, Ullal J: The role of PPARs in the microvascular dysfunction in diabetes. Vascul Pharmacol 2006;45:54-64.

16 Panunti B, Fonseca V: Effects of PPAR gamma agonists on cardiovascular function in obese, non-diabetic patients. Vascul Pharmacol 2006;45:29-35.

17 Blaschke F, Spanheimer R, Khan M, Law RE: Vascular effects of TZDs: new implications. Vascul Pharmacol 2006;45:3-18. 
18 Yousefipour Z, Hercule H, Truong L, Oyekan A, Newaz M: Ciglitazone, a peroxisome proliferator-activated receptor gamma inducer, ameliorates renal preglomerular production and activity of angiotensin II and thromboxane A2 in glycerol-induced acute renal failure. J Pharmacol Exp Ther 2007;322:461468.

19 Newaz M, Yousefipour Z, Oyekan A: Role of PPAR-gamma on the pathogenesis and vascular changes in glycerol-induced acute renal failure. Pharmacol Res 2006;54:234240.

-20 Efrati S, Berman S, Ilgiveav E, Averbukh Z, Weissgarten J: PPAR $\gamma$ activation inhibits angiotensin-II synthesis, apoptosis, and proliferation of mesangial cells from spontaneously hypertensive rats. Nephron Exp Nephrol 2007;106:107-112.

-21 Feldman RD, Gros R: Impaired vasodilator function in hypertension. The role of alterations in receptor- $G$ protein coupling. Trends Cardiovasc Med 1998;8:297-305.

22 Huang WC, Chio CC, Chi KH, Wu HM, Lin WW: Superoxide anion-dependent Raf/ MEK/ERK activation by peroxisome proliferator activated receptor gamma agonist 15deoxy-delta(12,14)-prostaglandin J(2), ciglitazone, and GW1929. Exp Cell Res 2002;277: 192-200.

23 Florza A, Penela P, Sarmago S, Mayor F: MAPK dependent degradation of $G$ protein coupled receptor kinase 2. J Biol Chem 2003; 278:29164-29173.

24 Pitcher JA, Tesmer JJ, Freeman JL, et al: Feedback inhibition of G-protein coupled receptor kinase 2 activity by extracellular signal regulated kinases. J Biol Chem 1999; 274:34531-34534.

25 Harris IS, Treskov I, Rowley MW, Heximer S, Kaltenbronn K, Finck BN, Gross RW, Kelly DP, Blumer KJ, Muslin AJ: G-protein signaling participates in the development of diabetic cardiomyopathy. Diabetes 2004;53: 3082-3090.

-26 Nishizuka M, Honda K, Tsuchiya T, Nishihara T, Imagawa M: RGS2 promotes adipocyte differentiation in the presence of ligand for peroxisome proliferator activated receptor $\gamma$. J Biol Chem 2001;276:29625-29627.
27 Iijima K, Yoshizumi M, Ako J, Eto M, Kim S, Hashimoto M, Sugimoto N, Liang YO, Sudoh N, Toba K, Ouchi Y: Expression of peroxisome proliferaor activated receptor gamma in rat aortic smooth muscle cells. Biochem Biophys Res Commun 1998;247:353-356.

-28 Law RE, Goetze S, Xi XP, Jackson S, Kawano Y, Demer L, Fishbein MC, Meehan WP, Hsueh WA: Expression and function of PPARgamma in rat and human vascular smooth muscle cells. Circulation 2000;101 1311-1318.

29 Marx N, Schonbeck U, Lazar MA, Libby P, Plutzky J: Peroxisome proliferator-activated receptor gamma activators inhibit gene expression and migration in human vascular smooth muscle cells. Circ Res 1998;83:10971103.

-30 Satoh H, Tsukamoto K, Hashimoto Y, Hashimoto N, Togo M, Hara M, Maekawa H, Isoo N, Kimura S, Watanabe T: Thiazolidinediones suppress endothelin-1 secretion from bovine vascular endothelial cells: a new possible role of PPARgamma on vascular endothelial function. Biochem Biophys Res Commun 1999;254:757-763.

31 Willson TM, Lambert MH, Kliewer SA: Peroxisome proliferator activated receptor gamma and metabolic disease. Annu Rev Biochem 2001;70:341-367.

32 Berger JP, Akiyama TE, Meinke PT: PPARs: therapeutic targets for metabolic diseases. Trends Pharmacol Sci 2005;26:244-251.

33 Lehrke M, Lazar MA: The many faces of PPARgamma. Cell 2005;123:995-999.

34 Chetty VT, Sharma AM: Can PPARgamma agonists have a role in the management of obesity related hypertension? Vascul Pharmacol 2006;45:46-53.

35 Ryan MJ, Didion SP, Mathur S, Faraci FM, Sigmund CD: PPARy agonists rosiglitazone improves vascular function and lowers blood pressure in hypertensive transgenic mice. Hypertension 2004;43:661-666.
36 Takeda K, Ichiki T, Tokunou T, Funakoshi Y, Ino N, Hirano K, Kanaide H, Takeshita A: Peroxisome proliferator-activated receptor gamma activators downregulate angiotensin II type 1 receptor in vascular smooth muscle cells. Circulation 2000;102:1834-1839.

37 Duan SZ, Usher MG, Mortensen RM: Peroxisome proliferator-activated receptor $\gamma$ mediated effects in the vasculature. Circ Res 2008;102:283-294.

-38 Guan Y, Zhang Y, Davis L, Breyer MD: Expression of peroxisome proliferator-activated receptors in urinary tract of rabbits and humans. Am J Physiol 1997;273:F1013F1022.

39 Yang T, Michele DE, Park J, et al: Expression of peroxisomal proliferator-activated receptors and retinoid $\mathrm{X}$ receptors in the kidney. Am J Physiol 1999;277:F966-F973.

40 Sarafidis PA, Lasaridis AN: Actions of PPAR agonists explaining a possible blood pressure lowering effect. Am J Hypertens 2006;19: 646-653.

41 Buckingham RE, Al-Barazanji KA, Toseland $\mathrm{CD}$, et al: Peroxisome proliferator-activated receptor-gamma agonist, rosiglitazone, protects against nephropathy and pancreatic islet abnormalities in Zucker fatty rats. Diabetes 1998;47:1326-1334.

42 Fujiwara K, Hayashi K, Ozawa Y, et al: Renal protective effect of troglitazone in Wistar fatty rats. Metabolism 2000;49:1361-1364.

43 Sironi AM, Vichi S, Gastaldelli A, et al: Effects of troglitazone on insulin action and cardiovascular risk factors in patients with non-insulin-dependent diabetes. Clin Pharmacol Ther 1997;62:194-202.

44 Bakris G, Viberti G, Weston WM, et al: Rosiglitazone reduces urinary albumin excretion in type 2 diabetes. J Hum Hypertens 2003; 17: $7-12$.

45 Sarafidis PA, Lasaridis AN, Nilsson PM, et al: The effect of rosiglitazone on urine albumin excretion in patients with type 2 diabetes mellitus and hypertension. Am J Hypertens 2005; 18:227-234.

-46 Carman CV, Parent JL, Day PW, Pronin AN, Sternweis PM, Wedegaertner PB, Gilman AG, Benovic JL, Kozasa T: Selective regulation of $\mathrm{G} \alpha \mathrm{q}$ by an RGS domain in the $\mathrm{G}$ protein coupled receptor kinase GRK-2. J Biol Chem 1999;274:34483-34492. 